University of Nebraska - Lincoln

DigitalCommons@University of Nebraska - Lincoln

$4-2001$

\title{
Molecular Phylogenetics of Western North American Frogs of the Rana boylii Species Group
}

\author{
J. Robert Macey \\ Washington University, St. Louis, macey@biology.wustl.edu \\ Jared L. Strasburg \\ Washington University, St. Louis, \\ Jennifer A. Brisson \\ University of Nebraska - Lincoln, jennifer.brisson@rochester.edu \\ Vance T. Vredenburg \\ University of California, Berkeley \\ Mark Jennings \\ Rana Resources, Davis, California
}

See next page for additional authors

Follow this and additional works at: https://digitalcommons.unl.edu/bioscifacpub

Part of the Life Sciences Commons

\begin{abstract}
Macey, J. Robert; Strasburg, Jared L.; Brisson, Jennifer A.; Vredenburg, Vance T.; Jennings, Mark; and Larson, Allan, "Molecular Phylogenetics of Western North American Frogs of the Rana boylii Species Group" (2001). Faculty Publications in the Biological Sciences. 82.

https://digitalcommons.unl.edu/bioscifacpub/82
\end{abstract}

This Article is brought to you for free and open access by the Papers in the Biological Sciences at DigitalCommons@University of Nebraska - Lincoln. It has been accepted for inclusion in Faculty Publications in the Biological Sciences by an authorized administrator of DigitalCommons@University of Nebraska - Lincoln. 


\section{Authors}

J. Robert Macey, Jared L. Strasburg, Jennifer A. Brisson, Vance T. Vredenburg, Mark Jennings, and Allan Larson

This article is available at DigitalCommons@University of Nebraska - Lincoln: https://digitalcommons.unl.edu/ 
Published in Molecular Phylogenetics and Evolution 19:1 (April 2001), pp. 131-143; doi: 10.1006/mpev.2000.0908

Copyright ( $\odot 2001$ by Academic Press. Used by permission. http://www.idealibrary.com

Submitted July 28, 2000; revised October 31, 2000; published online March 8, 2001

\title{
Molecular Phylogenetics of Western North American Frogs of the Rana boylii Species Group
}

\author{
J. Robert Macey, ${ }^{1}$ Jared L. Strasburg, ${ }^{1}$ Jennifer A. Brisson, ${ }^{1}$ \\ Vance T. Vredenburg, ${ }^{2}$ Mark Jennings, ${ }^{3}$ and Allan Larson ${ }^{1}$ \\ ${ }^{1}$ Department of Biology, Box 1137, Washington University, St. Louis, Missouri 63730 \\ ${ }^{2}$ Museum of Vertebrate Zoology, University of California, Berkeley, California 94720 \\ ${ }^{3}$ Rana Resources, 39913 Sharon Avenue, Davis, California 95616 \\ Corresponding author - J. R. Macey, email: macey@biology.wustl.edu
}

\begin{abstract}
Phylogenetic relationships among frogs of the genus Rana from western North America are investigated using 2013 aligned bases of mitochondrial DNA sequence from the genes encoding ND1 (subunit one of NADH dehydrogenase), tRNA ${ }^{\mathrm{Ile}}$, $\mathrm{tRNA}^{\mathrm{Gln}}$, $\mathrm{tRNA}^{\mathrm{Met}}, \mathrm{ND} 2, \mathrm{tRNA}^{\mathrm{Trp}}$, tRNA ${ }^{\mathrm{Ala}}$, tRNA $^{\text {Asn }}$, tRNA ${ }^{\text {Cys }}$, tRNA ${ }^{\text {Tyr }}$, and COI (subunit I of cytochrome $c$ oxidase), plus the origin for light-strand replication $\left(\mathrm{O}_{\mathrm{L}}\right)$ between the tRNA ${ }^{\text {Asn }}$ and tRNA ${ }^{\text {Cys }}$ genes. The aligned sequences contain 401 phylogenetically informative characters. A well-resolved phylogenetic hypothesis in which the Rana boylii species group (R. aurora, R. boylii, $R$. cascadae, R. muscosa, and R. pretiosa) is monophyletic is obtained. Molecular sequence divergence suggests that the $R$. boylii species group is approximately 8 million years old. The traditional hypothesis showing monophyly of the yellow-legged frogs ( $R$. boylii and R. muscosa) is statistically rejected in favor of a hypothesis in which $R$. aurora, $R$. cascadae, and R. muscosa form a clade. Reanalyses of published nuclear ribosomal DNA restriction-site data and allozymic data support a monophyletic $R$. boylii group, but do not effectively resolve relationships among species within this group. Eight populations of R. muscosa form two major clades separated by a biogeographic break in the Sierra Nevada of California. This biogeographic break is broadly concordant with breaks found in four other amphibian and reptilian taxa. The two major clades within $R$. muscosa are estimated to have diverged approximately 2.2 million years before present. Each of these major clades contains two subgroups showing approximately 1.5 million years divergence, implicating climatic effects of Pleistocene glaciation in vicariance. The four distinct subgroups of R. muscosa separated by at least 1.4 million years of evolutionary divergence are suggested as potential units for conservation.
\end{abstract}

Keywords: Amphibia, Anura, Ranidae, Rana, North America, California, biogeography, mitochondrial DNA, phylogenetics
$\mathrm{F}$ ive species of frogs in the family Ranidae occur strictly in western North America. These five species, Rana aurora, R. boylii, R. cascadae, R. muscosa, and $R$. pretiosa (here termed the $R$. boylii species group; Case, 1978), show variation in leg coloration, size, and elevational distribution. Phylogenetic relationships among the five species are a major subject of debate among evolutionary biologists (see Green, 1986b for a review). Despite numerous studies involving albumin immunology (Case, 1978; Farris et al., 1979, 1982; Post and Uzzell, 1981; Wallace et al., 1973), allozyme electrophoresis (Case, 1978; Green, 1986b), chromosomes (Green, 1986a), and restriction-enzyme cleavage analysis of nuclear rRNA genes (Hillis and Davis, 1986), no phylogenetic consensus has been achieved.

A long-standing view among biologists is that the two yellow-legged frogs, $R$. boylii (with a smaller body size and occurring at low elevation primarily in California) and $R$. muscosa (with a larger body size and occurring strictly at high elevations in California), form a monophyletic group (Green, 1986a, 1986b; Zweifel, 1955). The red-legged frog, $R$. aurora (which has a relatively large body size), is found in low-elevation areas along the Pacific coast and is often not grouped with the two yellowlegged frog species (Green, 1986a, 1986b; Zweifel, 1955). The other two species of western North American ranids occur at high elevations. $R$. cascadae (which has a relatively large body size) is found in the Cascade Range from northern California to Washington, and R. pretiosa (which has a relatively small body size and is sometimes divided into two species, $R$. pretiosa to the west and $R$. luteiventris to the east; Green et al., 1997) is found in the interior montane regions of northwestern North America. $R$. cascadae and R. pretiosa lack distinctive leg coloration and are not grouped with the two yellow-legged frog species ( $R$. boylii and R. muscosa) under the tradi- 
tional view of systematic relationships (Green, 1986a, 1986b; Zweifel, 1955).

An additional subject of debate concerns monophyly of the $R$. boylii species group with respect to the Eurasian $R$. temporaria species group and the North American species R. sylvatica (Case, 1978; Farris et al., 1979, 1982; Green, 1986b; Hillis and Davis, 1986; Post and Uzzell, 1981). The three main hypotheses proposed are: (1) the $R$. boylii species group represents a monophyletic taxon (Case, 1978; Hillis and Davis, 1986; Post and Uzzell, 1981; Uzzell and Post, $1986)$, (2) the $R$. temporaria species group is nested within the $R$. boylii species group (Farris et al., 1979, 1982), and (3) R. sylvatica is nested within the R. boylii species group (Dumas, 1966). All other Rana are considered only distantly related to the $R$. boylii species group (reviewed by Hillis and Davis, 1986).

Phylogenetic relationships of the five species of the $R$. boylii species group were examined using a 2013-base region of the mitochondrial genome spanning from the protein-coding gene ND1 (subunit one of NADH dehydrogenase) through the genes encoding tRNA ${ }^{\text {Ile, }}$, tRNAGln, tRNA ${ }^{\text {Met }}$, ND2, tRNA ${ }^{\text {Trp }}$, tRNA ${ }^{\text {Ala }}$, tRNA ${ }^{\text {Asn }}$, tRNACys, tRNA ${ }^{\mathrm{Tyr}}$, to the protein-coding gene COI (subunit I of cytochrome $c$ oxidase), and including the replication origin for the light strand $\left(\mathrm{O}_{\mathrm{L}}\right)$ between the tRNA ${ }^{\text {Asn }}$ and the tRNA ${ }^{C y s}$ genes. Monophyly of the R. boylii species group is tested with three outgroup taxa, $R$. catesbeiana, $R$. sylvatica, and $R$. temporaria. The $R$. boylii species group may be paraphyletic with respect to the $R$. temporaria group from Europe (Farris et al., 1979, 1982), in which $R$. sylvatica from North America is sometimes placed (Hillis and Davis, 1986). The eastern North American taxon, $R$. catesbeiana, is a standard outgroup taxon used in previous molecular phylogenetic studies and is included for consistency.

In California, a pattern of biogeographic fragmentation between northern and southern populations is emerging among codistributed species of amphibian and reptilian taxa in the Sierra Nevada [the salamanders, Ensatina eschscholtzii (Moritz et al., 1992) and Taricha torosa (Tan and Wake, 1995); a frog, Bufo canorus (Shaffer et al., 2000); and a snake, Lampropeltis zonata (RodriguezRobles et al., 1999)]. Eight populations within R. muscosa spanning the complete range of the species were sampled from California to examine the effect of this geographic break on the species. This species is nearing extinction in the northern Sierra Nevada, central Sierra Nevada, and southern California, and the results of this study may have management implications. Previously, populations from the Sierra Nevada have been considered a subspecies, R. muscosa sierrae (Camp, 1917), distinct from populations in southern California referred to as R. muscosa muscosa.
We reanalyze the existing allozymic data (Case, 1978; Green, 1986b) and variation in restriction-enzyme cleavage sites in nuclear rRNA genes (Hillis and Davis, 1986) in light of our newly published data.

\section{Materials and Methods}

\section{Specimen Information}

Museum numbers and localities for voucher specimens from which DNA was extracted and GenBank accession numbers are presented below. Acronyms are CAS for California Academy of Sciences, San Francisco, and MVZ for Museum of Vertebrate Zoology, University of California at Berkeley. An acronym followed by a dash RM represents a field number of the first author for an uncatalogued specimen being deposited in the Museum of Vertebrate Zoology. The population of $R$. sylvatica was introduced from Warren Co., Missouri, and the $R$. aurora population sampled is thought to have been introduced from Contra Costa Co., California (Green, 1985). The R. pretiosa population sampled is sometimes considered to belong to a distinct species, $R$. luteiventris (Green et al., 1997).

Rana catesbeiana: MVZ 196171, AF314016, 3.7 miles south of Pasco Co. line on Morris Bridge Rd., Hillsborough Co., Florida. R. sylvatica: MVZ-RM 10421, AF314017, Washington University Tyson Research Station, St. Louis Co., Missouri. R. temporaria: MVZ 218655, AF314018, Clear Meadow, approx. $2 \mathrm{~km}$ north of Tolstoy's Mansion, which is approx. $20 \mathrm{~km}$ south of Tula (54 $12^{\prime}$ N $37^{\circ} 37^{\prime}$ E), Tula Region, Russia. R. boylii: MVZ 148941, AF314019, along Pope Creek approx. 3 miles NW of Lake Barryessa, Napa Co., California. R. pretiosa: MVZ 137420, AF314020, 7.5 miles S Hwy 12 on Elk Meadows Rd., Marys Frog Pond, Missoula Co., Montana. R. aurora: MVZ 227645, AF314021, Little Warm Spring, Duckwater, Nye Co., Nevada. R. cascadae: MVZ 230719, AF314022, tributary of Wynoochee River, Olympic National Forest, Gray's Harbor Co., Washington. $R$. muscosa: (1) CAS 209386, AF314023, elev. 5820 ft., SE 1/4 of SE 1/ 4 Sec. 1, T. 24 N., R. 7 E., 39 57' 32.2 N $121^{\circ} 08^{\prime}$ 09.2 W, Silver Lake, Plumas National Forest, Plumas Co., California. (2) CAS 209668, AF314024, elev. 5840 ft., SW 1/ 4 of SE 1/ 4 Sec. 31, T. 21 N., R. 10E., 39 $43^{\prime} 8.53$ N $120^{\circ}$ 53' 56.94 W, Pine Grove Cemetery, Plumas National Forest, Plumas Co., California. (3) MVZ 180163, AF314025, elev. 9000 ft., Obel Lake, 2.4 miles SE Ebbetts Pass, Alpine Co., California. (4) MVZ 227662, AF314026, elev. $9200 \mathrm{ft} ., 1.7$ miles SW of Sonora Pass on Hwy 108, Tuolumne Co., California. (5) MVZ 226112, AF314027, elev. $10800 \mathrm{ft} ., 36.812^{\circ} \mathrm{N} 118.4216^{\circ} \mathrm{W}, 60$ Lake Basin, tributary to South Fork Woods Creek, Fresno Co., California. (6) MVZ 230140, AF314028, elev. 5400 ft., Bear Gulch tributary to San Gabriel River, San Gabriel Mountains, 
Table 1. Primers Used in This Study

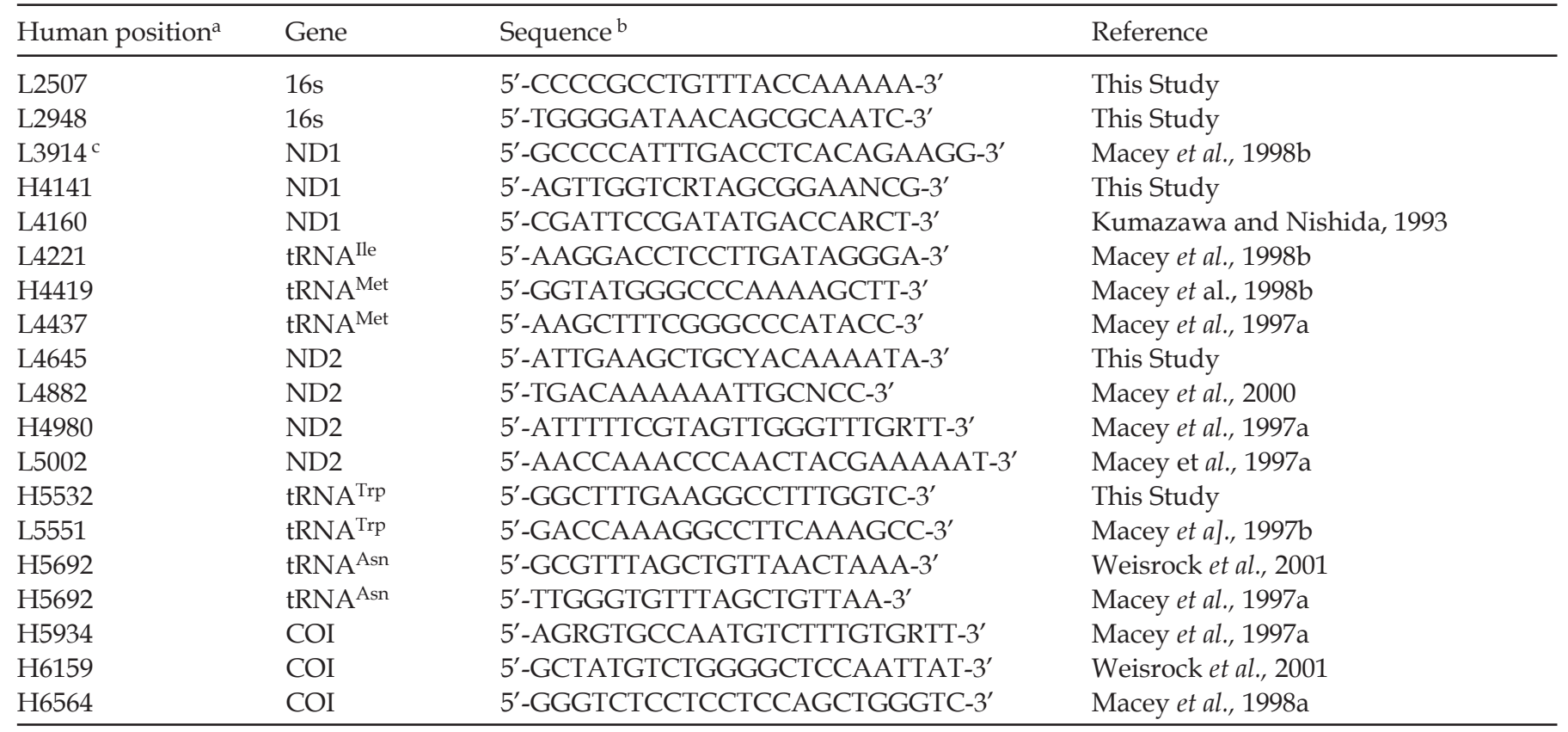

a Primers are designated by their 3' ends which correspond to the position in the human mitochondrial genome (Anderson et al., 1981) by convention. $\mathrm{H}$ and L designate primers whose extension produces the heavy and light strands, respectively.

${ }^{b}$ Positions with mixed bases are labeled with the standard one-letter code: $\mathrm{R}=\mathrm{G}$ or $\mathrm{A}, \mathrm{Y}=\mathrm{C}$ or $\mathrm{T}$, and $\mathrm{N}=$ any base.

c Previously incorrectly presented as L3878 in Macey et al. (1998b).

Los Angeles Co., California. (7) MVZ 230142, AF314029, elev. 6800 ft., North Fork San Jacinto River, San Jacinto Mountains, Riverside Co., California. (8) MVZ 230141, AF314030, elev. 1880 ft., East Fork City Creek, San Bernardino Mountains, San Bernardino Co., California.

\section{Laboratory Protocols}

Genomic DNA was extracted from liver using Qiagen QIAamp tissue kit. Amplification of genomic DNA was conducted using a denaturation at $94^{\circ} \mathrm{C}$ for $35 \mathrm{~s}$, annealing at $50^{\circ} \mathrm{C}$ for $35 \mathrm{~s}$, and extension at $70^{\circ} \mathrm{C}$ for $150 \mathrm{~s}$ with $4 \mathrm{~s}$ added to the extension per cycle, for 30 cycles. Negative controls were run for all amplifications. Amplified products were purified on $2.5 \%$ Nusieve GTG agarose gels and reamplified under similar conditions. Reamplified double-stranded products were purified on $2.5 \%$ acrylamide gels (Maniatis et al., 1982). Template DNA was eluted from acrylamide passively over 3 days with Maniatis elution buffer (Maniatis et al., 1982). Cycle-sequencing reactions were run using the Promega $\mathrm{fmol}$ DNA-sequencing system with a denaturation at $95^{\circ} \mathrm{C}$ for $35 \mathrm{~s}$, annealing at $45-60^{\circ} \mathrm{C}$ for $35 \mathrm{~s}$, and extension at $70^{\circ} \mathrm{C}$ for $1 \mathrm{~min}$ for 30 cycles. Sequencing reactions were run on Long Ranger sequencing gels for $5-12 \mathrm{~h}$ at $38-40^{\circ} \mathrm{C}$.

Amplifications from genomic DNA were done using different primer combinations (Table 1): (1) L2507H4419, (2) L3914-H4980, and (3) L4437-H6564. In addition, H5934 was used in combination with the following light-strand primers: L2948, L3914, L4160, L4221, and
L4437. Both strands were sequenced using the primers in Table 1. Primer numbers refer to the $3^{\prime}$ end on the human mitochondrial genome (Anderson et al., 1981), where $\mathrm{L}$ and $\mathrm{H}$ correspond to primers whose extension produces light and heavy strands, respectively.

\section{Phylogenetic Analysis}

DNA sequences were aligned manually. Protein-coding sequences were translated to amino acids using MacClade (Maddison and Maddison, 1992) for confirmation of alignment. Transfer-RNA secondary structure was determined manually using the criteria of Kumazawa and Nishida (1993) to ensure proper alignment (Macey and Verma, 1997).

Phylogenetic trees were estimated using PAUP* beta version 4.0b2 (Swofford, 1999) with branch-and-bound searches. Bootstrap resampling was applied to assess support for individual nodes with 500 bootstrap replicates using branch-and-bound searches. Bootstrap analysis of the allozymic data of Green (1986b) using allelic combinations as character states with step matrices featured 10 heuristic searches with random addition of sequences per bootstrap replicate. Decay indices (= "branch support" of Bremer, 1994) were calculated for all internal branches of the trees as follows. Branch-and-bound searches, which retained suboptimal trees, were run for all nodes; the decay index was then tabulated as the difference in length between the shortest tree that did not contain a particular node and the overall shortest tree. 
The Wilcoxon signed-ranks test (Felsenstein, 1985; Templeton, 1983) was used to examine statistical significance of the overall shortest tree relative to alternative hypotheses. This test asks whether the most parsimonious tree is significantly shorter than an alternative or whether their differences in length can be attributed to chance alone (Larson, 1998). Wilcoxon signed-ranks tests were conducted as one- and two-tailed tests. Felsenstein (1985) showed that one-tailed probabilities are close to the exact probabilities for this test but not always conservative, whereas the two-tailed test is always conservative. Tests were conducted using PAUP* beta version 4.0b2 (Swofford, 1999), which incorporates a correction of tied ranks. When appropriate, the large-sample approximation for probabilities given in PAUP* (Swofford, 1999) was used. For comparisons among R. muscosa populations, for which the large-sample approximation is not appropriate, statistical significance was determined using Table A.4 from Hollander and Wolfe (1973).

Alternative phylogenetic hypotheses were tested using the most parsimonious phylogenetic topologies compatible with them. To find the most parsimonious tree(s) compatible with a particular phylogenetic hypothesis, phylogenetic topologies were constructed using MacClade (Maddison and Maddison, 1992) and analyzed as constraints using PAUP* beta version 4.0b2 (Swofford, 1999) with branch-and-bound searches.

\section{Cladistic Analyses of Allozymic Data}

Previously reported allozymic data of Case (1978) and Green (1986b) were coded in two ways for cladistic phylogenetic analysis. Although presence-absence coding of alleles has received considerable criticism for a lack of independence of alleles and the possibility of no allele being reconstructed for an ancestral node, it remains the method that provides the greatest amount of resolution (see Macey et al., 1999a). Alternatively, combinations of alleles for a particular locus may be coded as discrete character states (Buth, 1984). If step matrices are used to connect character states, a greater amount of information can be retained (Mabee and Humphries, 1993). In our analysis, step matrices were constructed on the basis of gains and losses of alleles. For example, a fixed difference between two alleles was counted as two steps, one allele lost and another gained. In the case of a two-allele polymorphism in one population with one allele shared with another monomorphic population, a single gain or loss was counted as a single step. Additional polymorphisms were counted in the same manner. Our analysis excluded alleles scored as absent ("abs") by Case (1978).

\section{Results}

Sequences ranging in size from 2008 to 2012 bases of mitochondrial DNA for 15 taxa of Rana are aligned as
2013 positions. Sequences reported here correspond to positions 3892 to 5936 on the human mitochondrial genome (Anderson et al., 1981) and contain the genes encoding ND (subunit one of NADH dehydrogenase) tRNA ${ }^{\text {Ile }}$, tRNA $^{\text {Gln }}$, tRNA ${ }^{\text {Met }}, N^{2} 2$, tRNA ${ }^{\text {Trp }}$, tRNA ${ }^{\text {Ala }}$, tRNA ${ }^{\text {Asn }}$, tRNA $^{\text {Cys, }}$ tRNA ${ }^{\mathrm{Tyr}}$, and COI (subunit I of cytochrome $c$ oxidase), plus the $\mathrm{O}_{\mathrm{L}}$ between the tRNA ${ }^{\text {Asn }}$ and tRNA ${ }^{\text {Cys }}$ genes. Length variation is minimal in this data set, and all 2013 aligned positions were analyzed phylogenetically. The second-to-last codon position in the ND2 gene is absent in the R. muscosa populations sampled; three gaps are placed at positions 1601-1603. Among tRNA genes, length variation is observed only in the sequences encoding the TYC (T) loop of tRNA ${ }^{\mathrm{Tyr}}$. The R. muscosa sample from the San Jacinto Mountains has a sequence 1 base longer, and the R. muscosa sample from Fresno County has a sequence 1 base shorter, than the sequences derived from other taxa sampled. A single gap is placed at position 1929 in all sequences except the sequence derived from the San Jacinto Mountains sample of R. muscosa. An additional gap is placed at position 1928 in the sequence derived from the Fresno County sample of R. muscosa. Between the tRNA ${ }^{\text {Ala }}$ and the tRNA ${ }^{\text {Asn }}$ genes, a single gap is placed at position 1749 in the three outgroup taxa ( $R$. catesbeiana, R. sylvatica, and R. temporaria). In the origin of light-strand replication $\left(\mathrm{O}_{\mathrm{L}}\right)$, a gap is placed at position 1836 in the $R$. catesbeiana sequence, and a gap is placed at position 1835 in the $R$. boylii sequence.

\section{Authentic Mitochondrial DNA}

Several observations suggest that the DNA sequences analyzed here are from the mitochondrial genome and do not represent nuclear-integrated copies of mitochondrial genes (see Zhang and Hewitt, 1996). Protein-coding genes do not have premature stop codons, suggesting that these sequences represent functional copies that encode a protein. Transfer-RNA genes appear to code for tRNAs with stable secondary structures, indicating functional genes. The presence of strand bias further supports our conclusion that the 15 DNA sequences reported here are from the mitochondrial genome. The sequences reported here show strong strand bias against guanine on the light strand $(\mathrm{G}=12.6-14.1 \%, \mathrm{~A}=26.5-28.3 \%, \mathrm{~T}=$ $28.7-31.0 \%$, and $C=27.8-30.9 \%$, which is characteristic of the mitochondrial genome but not the nuclear genome. See Macey et al. (1998b) for similar strand bias in bufonid frogs for the same region of the mitochondrial genome.

\section{Genic Variation}

Different levels of DNA substitutional variation are observed among the three protein-coding genes, eight tRNA-coding genes, and three noncoding regions (Table 2). All of the genes sequenced except the tRNA ${ }^{\text {Met }}$ gene contain phylogenetically informative characters. The ND1 and ND2 protein-coding genes contain phy- 
logenetic information in first, second, and third codon positions. Most of the variation and phylogenetically informative sites are from protein-coding regions. Only $13 \%$ of variable and $12 \%$ of phylogenetically informative sites are from tRNA genes and noncoding regions. Of the 354 phylogenetically informative characters from protein-coding regions, 264 are from third positions of codons. Third-position sites account for approximately two thirds of the phylogenetically informative sites in the total data set. Only 23 phylogenetically informative sites occur in regions encoding stems of tRNAs, suggesting that compensatory substitutions do not compromise the phylogenetic analysis.

\section{Phylogenetic Relationships}

A single tree results from the parsimony analysis of the 2013 aligned DNA sequences containing 401 phylogenetically informative base positions (Figure 1, Table 2). Phylogenetic relationships are well resolved for most nodes of the tree. Relative to $R$. catesbeiana and $R$. sylvat$i c a, R$. temporaria appears as the sister taxon (bootstrap $96 \%$; decay index 18) to a monophyletic R. boylii group (bootstrap 96\%; decay index 13). Within the R. boylii group, $R$. boylii and $R$. pretiosa are weakly supported as sister species (decay index 1 ). They form the sister taxon to a well-supported clade containing R. aurora, R. casca- dae, and R. muscosa populations (bootstrap 95\%; decay index 8). Within this clade, relationships among species are not well resolved, but $R$. cascadae and R. muscosa appear as sister taxa (bootstrap 54\%; decay index 3 ).

Among R. muscosa populations, two major clades are evident: a northern group (bootstrap 88\%; decay index 6) consisting of samples from Plumas, Alpine, and Tuolumne Counties of California in the Sierra Nevada, and a southern group (bootstrap 92\%; decay index 7) consisting of samples from the southern Sierra Nevada, the San Gabriel Mountains, the San Jacinto Mountains, and the San Bernardino Mountains of southern California. Within the northern clade, populations from Plumas County in the northern Sierra Nevada form a well-supported clade (bootstrap 100\%; decay index 11), and populations in the central Sierra Nevada also form a wellsupported clade (bootstrap 100\%; decay index 12). In the southern clade, the population from Fresno County in the southern Sierra Nevada forms the sister taxon to the three populations from southern California with strong support (bootstrap 100\%; decay index 12). The relationships between the three southern California populations are not well resolved, with the San Gabriel and San Jacinto mountain populations grouped together (bootstrap 64\%; decay index 1).

The phylogenetic analysis of restriction sites in the nuclear ribosomal RNA genes of Hillis and Davis (1986)

Table 2. Distribution of Phylogenetically Informative and Variable Positions

\begin{tabular}{|c|c|c|c|c|c|c|c|c|c|c|c|c|}
\hline & \multicolumn{3}{|c|}{$\begin{array}{l}\text { ND1 codon } \\
\text { positions }\end{array}$} & \multicolumn{2}{|c|}{$\mathrm{tRNA}^{\text {Ile }}$} & \multicolumn{2}{|c|}{$\mathrm{tRNA}^{\mathrm{Gln}}$} & \multicolumn{2}{|c|}{$\mathrm{tRNA}^{\mathrm{Met}}$} & \multicolumn{3}{|c|}{$\begin{array}{l}\text { ND2 codon } \\
\text { positions }\end{array}$} \\
\hline & 1st & 2nd & $3 r d$ & Stem & Nonstem & Stem & $\overline{\text { Nonstem }}$ & Stem & Nonstem & $1 \mathrm{st}$ & 2nd & $3 r d$ \\
\hline Variable sites & 28 & 8 & 107 & 5 & 4 & 7 & 7 & - & 2 & 99 & 32 & 279 \\
\hline Informative sites & \multicolumn{2}{|r|}{-} & \multicolumn{2}{|c|}{4} & 5 & \multicolumn{2}{|r|}{3} & \multicolumn{2}{|c|}{-} & 2 & & 1 \\
\hline Variable sites & \multicolumn{2}{|r|}{1} & \multicolumn{2}{|c|}{6} & 7 & \multicolumn{2}{|r|}{4} & \multicolumn{2}{|c|}{1} & 5 & & 2 \\
\hline
\end{tabular}

\begin{tabular}{|c|c|c|c|c|c|c|c|c|c|}
\hline & \multirow{2}{*}{$\begin{array}{l}\text { Noncoding a } \\
\text { region No. } 2\end{array}$} & \multicolumn{2}{|c|}{$\mathrm{tRNA}^{\mathrm{Cys}}$} & \multicolumn{2}{|c|}{$\mathrm{tRNA}^{\mathrm{Tyr}}$} & \multirow{2}{*}{$\begin{array}{l}\text { Noncoding a } \\
\text { region No. } 3\end{array}$} & \multicolumn{3}{|c|}{ COI codon positions } \\
\hline & & Stem & Nonstem & Stem & Nonstem & & $1 \mathrm{st}$ & 2nd & 3rd \\
\hline Informative sites & 4 & 5 & 6 & 3 & 3 & - & - & - & 2 \\
\hline
\end{tabular}

\begin{tabular}{|c|c|c|c|c|c|c|c|}
\hline Total & \multicolumn{3}{|c|}{ Protein coding codon positions } & \multicolumn{2}{|c|}{ tRNA coding } & $\begin{array}{l}\text { Noncoding } \\
\text { regions }\end{array}$ & $\begin{array}{l}\text { All aligned } \\
\text { sequence }\end{array}$ \\
\hline Informative sites & 77 & 13 & 264 & 23 & 20 & 4 & 401 \\
\hline
\end{tabular}

\footnotetext{
a Noncoding region No. 1 is between the tRNA ${ }^{\text {Ala }}$ and the tRNA Asn genes. Noncoding region No. 2 is the $\mathrm{O}_{\mathrm{L}}$. Noncoding region No. 3 is between the tRNA ${ }^{\mathrm{Tyr}}$ and the COI genes.
} 


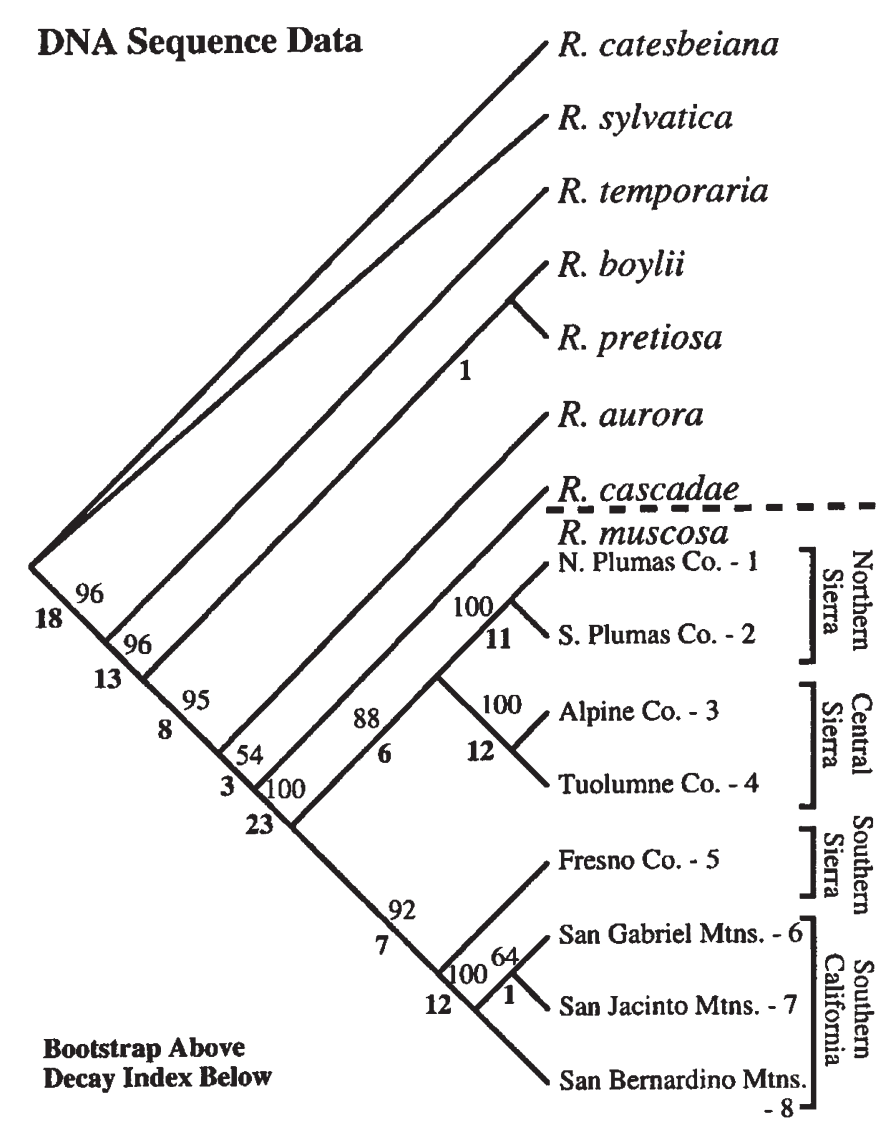

Figure 1. Single most parsimonious tree produced from analysis of the 2013 aligned (401 phylogenetically informative) positions. The tree has a length of 1240 steps. Bootstrap values are presented above branches and decay indices below branches. Note that the yellow-legged frogs, $R$. boylii and $R$. muscosa, do not form a monophyletic group.

produces a single most parsimonious tree (Figure 2). Relationships are not well supported, with all branches in the tree having decay indices of only 1 or 2 . The topology is not the same as that produced from the mitochondrial DNA sequences, although the $R$. boylii group is monophyletic, and the yellow-legged frogs (R. boylii and R. muscosa) do not form a monophyletic group.

Phylogenetic relationships from reanalysis of allozymic data (Case, 1978; Green, 1986b) are largely the same whether analyzed with allelic combinations as character states using step matrices or as presence/absence coding of alleles (Figure 3). The allozymic data of Case (1978) recover a single most parsimonious tree in all analyses, with poor support for phylogenetic relationships among species. The topology differs from results of other data sets, although the $R$. boylii group is monophyletic and the yellow-legged frogs do not form a monophyletic group.

The allozymic data of Green (1986b) recover two equally most parsimonious trees in the analysis applying the presence or absence of alleles, whereas the analysis of allelic combinations as character states with

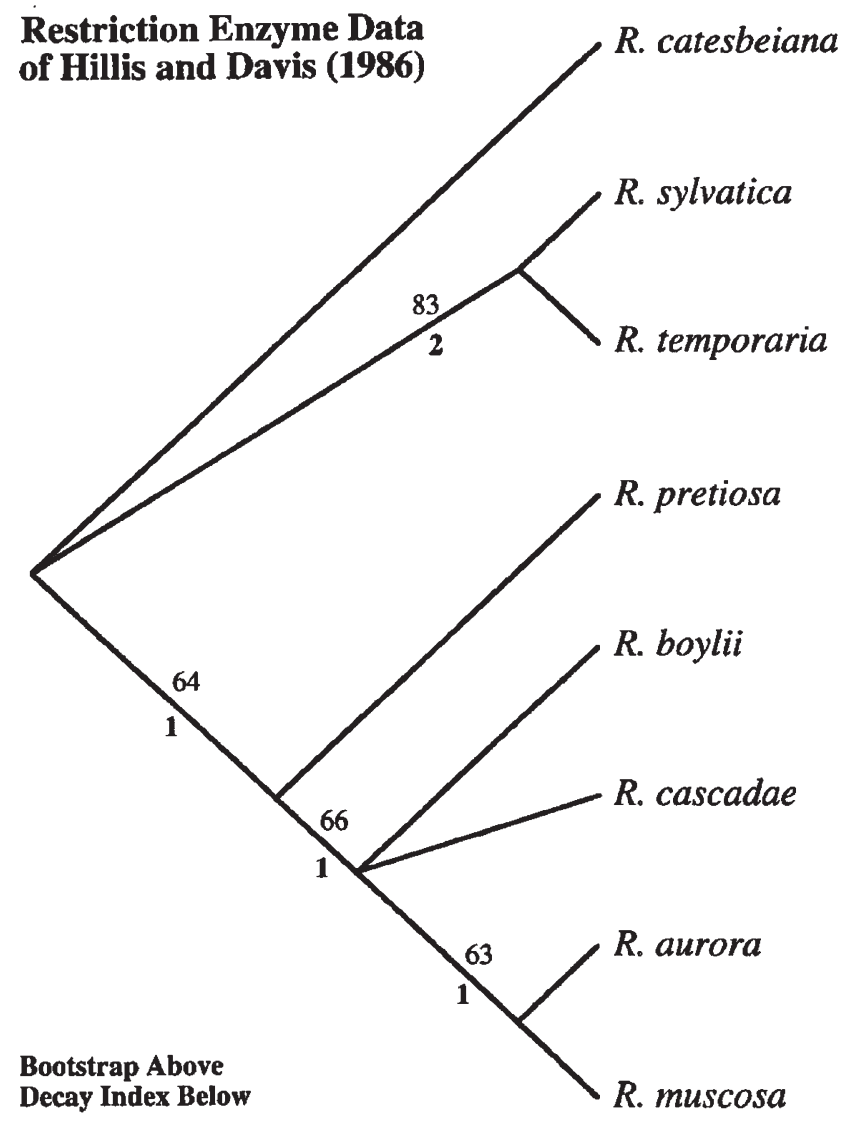

Figure 2. Single most parsimonious tree produced from analysis of the 76 (5 phylogenetically informative) nuclear ribosomal RNA-gene restriction sites of Hillis and Davis (1986). The tree has a length of 27 steps. Bootstrap values are presented above branches and decay indices below branches. Note that the yellow-legged frogs, R. boylii and R. muscosa, do not form a monophyletic group.

step matrices produces three equally most parsimonious trees (Figure 4). The two trees found in the former analysis also appear in the latter analysis. These trees differ in topology from results of other data sets; however, both analyses recover a monophyletic $R$. boylii group. Phylogenetic positions of the yellow-legged species (R. boylii and R. muscosa) are not well resolved, with only the analysis applying the presence or absence of alleles weakly suggesting grouping of the two species. These trees differ from the trees derived from mitochondrial DNA sequences, the nuclear RNA restriction-site data of Hillis and Davis (1986), and the allozymic data of Case (1978).

Phylogenetic results derived from analyses of mitochondrial DNA sequences provide a more robust estimate of relationships than previously published data. The phylogenetic hypothesis derived from mitochondrial DNA sequences (Figure 1) is tested against alternative topologies by applying the Wilcoxon signed-ranks test (Felsenstein, 1985; Templeton, 1983) to the mitochondrial DNA data (Table 3). 


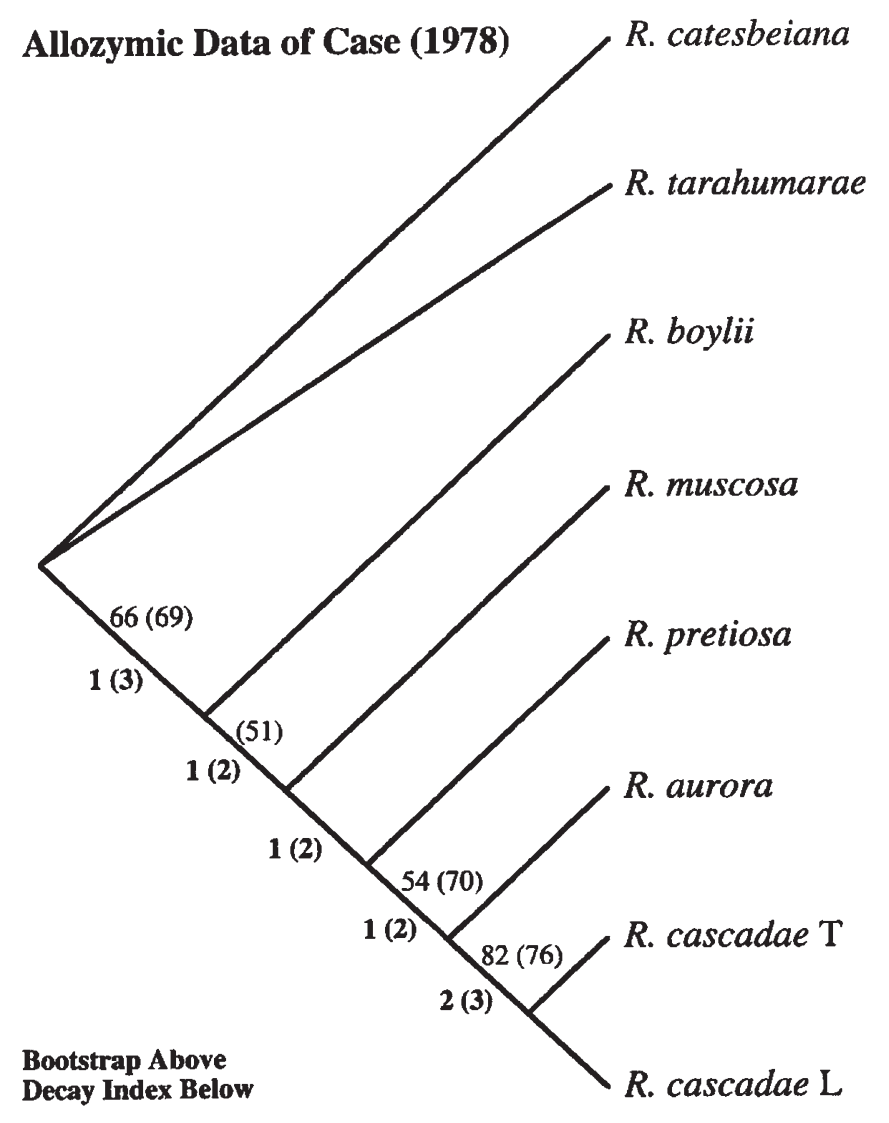

Figure 3. Phylogenetic tree from analyses of allozymic data from Case (1978). Bootstrap values are presented above branches and decay indices below branches. Values outside parentheses represent those derived when the data were coded as the presence or absence of the 79 (39 informative) individual alleles. Values inside parentheses represent those derived when the 17 loci (15 informative) were coded using allelic combinations as character states with step matrices. Both analyses produce the same single most parsimonious topology. The analysis applying the presence or absence of alleles produces a tree of 106 steps, whereas the analysis of allelic combinations as character states with step matrices produces a tree of 114 steps. "T" and "L" represent Trinity and Lassen County populations of $R$. cascadae in California, respectively. Note that the yellow-legged frogs, $R$. boylii and $R$. muscosa, do not form a monophyletic group.

(1). All analyses presented here support monophyly of the $R$. boylii group. The shortest alternative tree in which the R. boylii group is not monophyletic (A1 in Appendix) cannot be rejected in favor of the overall shortest tree (Figure 1), although this test is close to significance using the one-tailed test (test 1 in Table 3).

(2). Only the analysis applying the presence or absence of alleles from Green (1986b) suggests that $R$. boylii and $R$. muscosa are sister taxa. The mitochondrial DNA data reject the shortest alternative tree (B1 in Appendix) showing $R$. boylii and R. muscosa as a monophyletic group in favor of the overall shortest tree (Figure 1) using the two-tailed test (test 2 in Table 3).

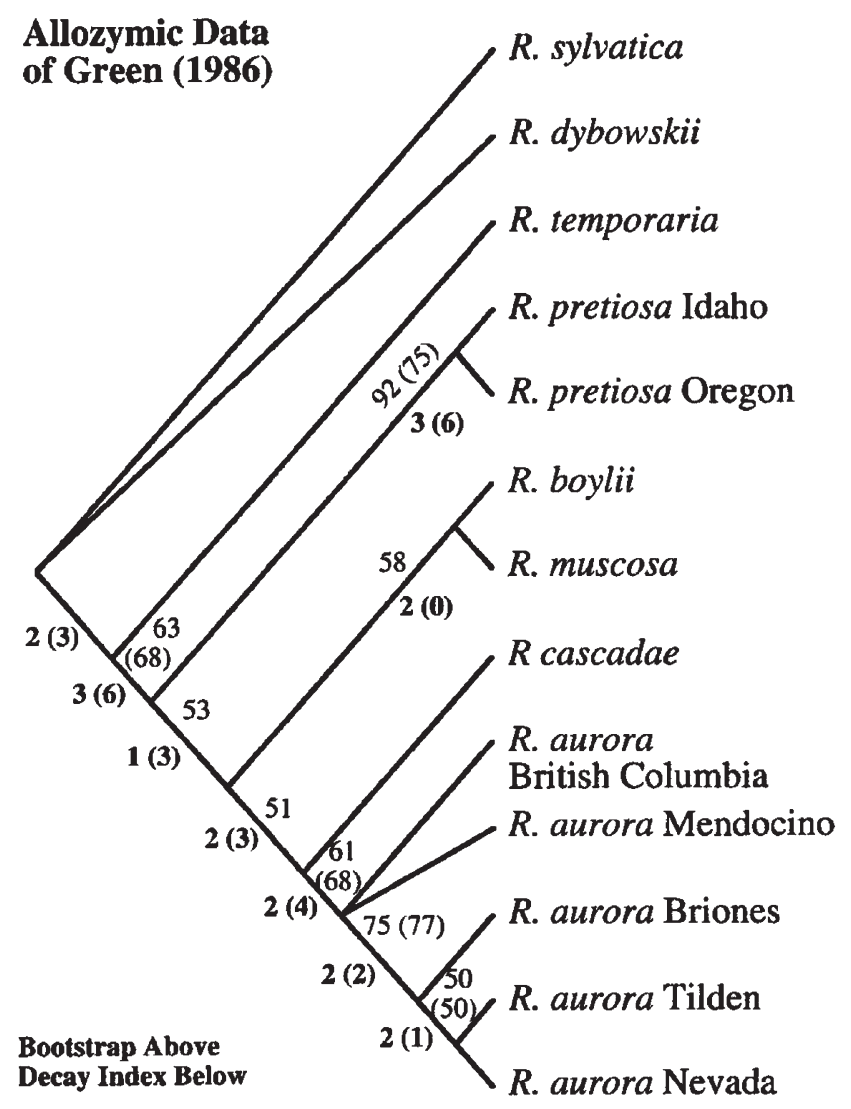

Figure 4. Phylogenetic tree from analyses of allozymic data from Green (1986b). Bootstrap values are presented above branches and decay indices below branches. Values outside parentheses represent those derived when the data are coded as the presence or absence of the 111 (72 informative) individual alleles. Values inside parentheses represent those derived when the 27 loci (24 informative) are coded using allelic combinations as character states and analyzed with step matrices. The analysis applying the presence or absence of alleles produces two equally most parsimonious trees of 197 steps, whereas the analysis of allelic combinations as character states with step matrices produces three equally most parsimonious trees of 209 steps. The two trees found in the analysis applying the presence or absence of alleles also appear in the analysis of allelic combinations as character states with step matrices. The only interspecific relationship not resolved in the analysis of allelic combinations as character states with step matrices is the grouping of $R$. boylii and $R$. muscosa, indicated by the zero decay index in parentheses. Within $R$. aurora, Mendocino represents the Mendocino County population from California. Briones and Tilden are regional parks in Contra Costa County of California. The sample from Nevada is hypothesized to be introduced from Contra Costa County, California and this is the same population examined for mitochondrial DNA sequence.

(3). The DNA sequence data presented here do not support monophyly of Sierra Nevada populations of $R$. muscosa. The shortest alternative tree (C1 in Appendix) showing Sierra Nevada populations of R. muscosa as a monophyletic group is rejected in favor of the overall shortest tree (Figure 1) using the one-tailed test (test 3 in Table 3). 
(4). The DNA sequence data suggest that the northern Sierra Nevada populations of $R$. muscosa form a clade. The shortest alternative tree (D1 in Appendix) in which northern Sierra Nevada populations of R. muscosa do not form a monophyletic group is rejected in favor of the overall shortest tree (Figure 1) using the two-tailed test (test 4 in Table 3).

(5). The DNA sequence data suggest that the central Sierra Nevada populations of $R$. muscosa form a clade. The shortest alternative tree (E1 in Appendix) in which central Sierra Nevada populations of R. muscosa do not form a monophyletic group is rejected in favor of the overall shortest tree (Figure 1) using the two-tailed test (test 5 in Table 3 ).

(6). The DNA sequence data suggest that southern California populations of $R$. muscosa form a clade. The shortest alternative tree (F1 in Appendix) in which southern California populations of R. muscosa do not form a monophyletic group is rejected in favor of the overall shortest tree (Figure 1) using the two-tailed test (test 6 in Table 3).

Because the ribosomal DNA restriction-site data and allozymic data provide few phylogenetically informative characters and only weak branch support for their favored topologies (Figures 2-4), further statistical analysis of these data is not warranted.

\section{Discussion}

All phylogenetic analyses of the mitochondrial DNA sequence data, nuclear restriction-site data, and allozymic data suggest that the $R$. boylii group is monophyletic. The DNA sequence data show strong support for this hypothesis, with a bootstrap value of $96 \%$ and a decay index of 13. Although the alternative hypothesis of a nonmonophyletic $R$. boylii group cannot be rejected using the Wilcoxon signed-ranks test, the $P$ value is almost significant $(P=0.07$; Table 3$)$. Our results supporting monophyly of the $R$. boylii group agree with the albumin immunological studies of Case (1978) and Post and Uzzell (1981) and conflict with conclusions drawn from reanalyses of those data by Farris et al. $(1979,1982)$.

The mitochondrial DNA sequence data suggest that $R$. aurora, $R$. cascadae, and $R$. muscosa form a clade within the $R$. boylii species group, but do not strongly resolve other interspecific relationships within this group. The phylogenetic analyses of the nuclear restriction-site data, allozymic data, and mitochondrial DNA sequence data all produce different topologies within the R. boylii species group. The nuclear restriction-site and allozymic data provide poor support for phylogenetic relationships among these species. Only the reanalysis using the presence/absence of alleles as character states in the allozymic data of Green (1986b) suggests a sister taxon relationship between the yellow-legged frogs, $R$. boylii and $R$. muscosa, with weak support (bootstrap 58\%. decay index 2). Green (1986a) also presented karyological evidence suggesting that the yellow-legged frogs form a monophyletic group. However, this study did not include an outgroup, and only two characters (characters 1 and 3 in Table 3 of Green, 1986a) with questionable homology of character states support a sister taxon relationship of $R$. boylii and R. muscosa. Published data therefore provide little support for monophyly of a group comprising the yellow-legged frogs. The mitochondrial DNA sequence data strongly reject the grouping of $R$. boylii with $R$. muscosa using the Wilcoxon signed-ranks test (Table 3 ).

\section{Age of the R. boylii Species Group}

The region of mitochondrial DNA sequenced has be been found to evolve with an approximately consistent rate of change per lineage per million years among a wide range of vertebrates [fish $0.65 \%$ (Bermingham et al., 1997); hynobiid salamanders $0.64 \%$ (unpublished data of

Table 3. Results of Wilcoxon Signed-Ranks Tests

\begin{tabular}{|c|c|c|c|c|c|}
\hline Alternative hypotheses tested & Trees $^{\mathrm{a}}$ & $N^{\mathrm{b}}$ & $T_{\mathrm{s}}^{\mathrm{c}}$ & $Z^{\mathrm{d}}$ & $P^{\mathrm{e}}$ \\
\hline 1. Nonmonophyly of the R. boylii group & Fig. 1 vs A1 & 77 & 1248 & 1.48 & 0.07 \\
\hline 2. R. boylii and R. muscosa are sister species & Fig. 1 vs B1 & 103 & 2060 & 2.33 & $0.01^{* *}$ \\
\hline 3. Sierra Nevada R. muscosa populations form a clade & Fig. 1 vs $C 1$ & 15 & 32 & - & $0.05^{*}$ \\
\hline 4. Northern Sierra Nevada R. muscosa populations do not form a clade & Fig. 1 vs D1 & 11 & 0 & - & $<0.01^{* *}$ \\
\hline 5. Central Sierra Nevada R. muscosa populations do not form a clade & Fig. 1 vs E1 & 16 & 17 & - & $<0.01^{* *}$ \\
\hline
\end{tabular}

\footnotetext{
a See Appendix for phylogenetic topologies used in tests.
}

${ }^{b}$ Number of characters differing in minimum numbers of changes on paired topologies.

${ }^{\mathrm{c}} T_{\mathrm{s}}=$ test statistic of the Wilcoxon signed-ranks test derived from PAUP* (Swofford, 1999).

d Normal approximation for Wilcoxon signed-ranks test ( $Z$ values not provided for $N<25)$. Statistical significance for $N<25$ is determined using Table A.4 from Hollander and Wolfe (1973).

e Asterisks indicate a significant difference between the overall shortest tree and an alternative tree. One asterisk denotes significance using the one-tailed probability only, and two asterisks denote significance using the two-tailed probability for the Wilcoxon signed-ranks test. One-tailed probabilities are shown and two-tailed probabilities are double these values. A significant result means that the alternative hypothesis as stated can be rejected. 
the authors); frogs of the genus Bufo 0.69\% (Macey et al., 1998b); lizards of the genus Laudakia 0.65\% (Macey et al., 1998a); lizards of the genus Teratoscincus $0.57 \%$ (Macey et al., 1999b)]. The calibrations derived from hynobiid salamanders and Laudakia lizards are each based on four geologic dates and are therefore the most reliable calibrations, suggesting a pairwise rate of change of $1.3 \%$ sequence divergence per million years.

Applying this calibration yields an age of approximately 8 million years for the $R$. boylii species group (Table 4). Case (1978), using the immunological distance/ time relationship of Wilson et al. (1977), found the age of the group to be approximately 12 million years, which is slightly older than our estimate derived from mitochondrial DNA.

Case (1978) suggested that the R. boylii species group diverged from the $R$. temporaria species group approximately 27 million years before present (MYBP). Using the mitochondrial DNA sequence data and the rate of sequence evolution given above, this divergence is dated at approximately 12 MYBP. However, after 10 million years, mitochondrial DNA is expected to saturate (Moritz et al., 1987): hence, a linear relationship of nucleotide substitutions with time is not anticipated. Therefore, the date of 12 MYBP is likely to be an underestimate of this divergence, but still not congruent with the date of 27 MYBP suggested by Case (1978).

\section{Geographic Fragmentation within R. muscosa}

The phylogenetic analysis of mitochondrial DNA sequences reveals two major clades within R. muscosa (Figure 5). A northern clade contains populations from the northern and central Sierra Nevada, and a southern clade contains populations from the southern Sierra Nevada

\section{Relationships and Timing of Divergence Among R. muscosa Populations}

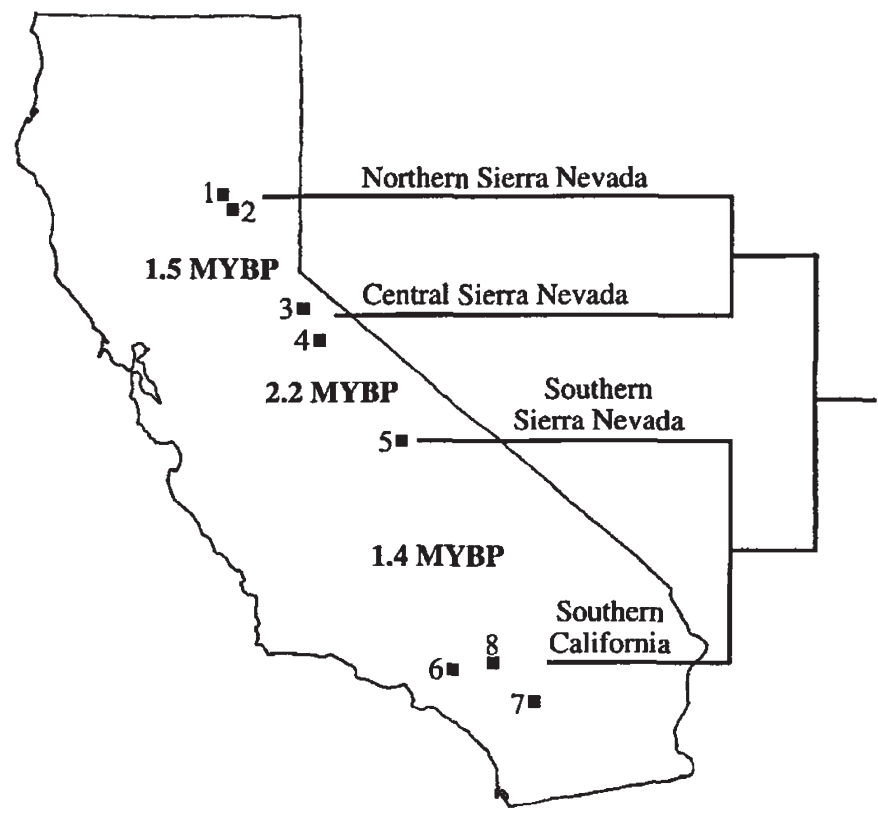

Figure 5. Map showing locations of $R$. muscosa populations sampled in California. Samples are numbered as in Figure 1 and under "Materials and Methods." The four major clades are labeled on branches of the phylogenetic tree to the right. Suggested dates of divergence between the clades are derived by applying the pairwise rate of $1.3 \%$ sequence divergence per million years. Note the similarity in timing of divergence at approximately 1.5 million years within each of the two major clades.

Table 4. Pairwise Comparisons of DNA Sequences among Western North American Rana and Related Taxa ${ }^{a}$

$\begin{array}{lrrrrrrrrrrrrrrr} & 1 & 2 & 3 & 4 & 5 & 6 & 7 & 8 & 9 & 10 & 11 & 12 & 13 & 14 & 15 \\ \text { 1. R. catesbeiana } & - & 14.0 \% & 16.6 \% & 13.8 \% & 14.8 \% & 14.9 \% & 14.9 \% & 15.3 \% & 15.4 \% & 14.9 \% & 14.9 \% & 15.0 \% & 14.9 \% & 15.1 \% & 15.0 \% \\ \text { 2. } \text {.sylvatica } & 282 & - & 17.8 \% & 15.2 \% & 15.6 \% & 15.5 \% & 14.8 \% & 15.3 \% & 15.4 \% & 15.4 \% & 15.6 \% & 15.6 \% & 16.0 \% & 16.2 \% & 16.0 \% \\ \text { 3. R. temporaria } & 334 & 358 & - & 15.3 \% & 16.0 \% & 15.7 \% & 16.5 \% & 15.5 \% & 15.5 \% & 15.7 \% & 15.6 \% & 15.6 \% & 15.6 \% & 15.9 \% & 15.6 \% \\ \text { 4. R. pretiosa } & 277 & 306 & 308 & - & 10.3 \% & 10.2 \% & 10.1 \% & 9.4 \% & 9.7 \% & 9.1 \% & 9.3 \% & 9.4 \% & 9.4 \% & 9.7 \% & 9.5 \% \\ \text { 5. R. boylii } & 297 & 314 & 321 & 208 & - & 12.1 \% & 10.4 \% & 11.0 \% & 11.1 \% & 10.8 \% & 10.8 \% & 11.0 \% & 11.4 \% & 11.6 \% & 11.4 \% \\ \text { 6. R. aurora } & 300 & 312 & 316 & 205 & 244 & - & 7.9 \% & 7.8 \% & 7.9 \% & 7.8 \% & 8.0 \% & 7.9 \% & 8.2 \% & 8.4 \% & 8.2 \% \\ \text { 7. R.cascadae } & 300 & 297 & 332 & 203 & 210 & 159 & - & 7.0 \% & 7.0 \% & 7.2 \% & 7.3 \% & 7.1 \% & 7.1 \% & 7.4 \% & 7.3 \% \\ \text { 8. R. muscosa-1 } & 308 & 308 & 311 & 189 & 220 & 157 & 141 & - & 0.2 \% & 1.8 \% & 2.1 \% & 2.6 \% & 2.9 \% & 3.0 \% & 2.9 \% \\ \text { 9. R. muscosa-2 } & 309 & 309 & 312 & 194 & 223 & 158 & 140 & 5 & - & 1.9 \% & 2.1 \% & 2.7 \% & 2.9 \% & 3.1 \% & 2.9 \% \\ \text { 10. R. muscosa-3 } & 300 & 309 & 315 & 183 & 216 & 157 & 144 & 37 & 38 & - & 0.4 \% & 2.6 \% & 2.8 \% & 3.0 \% & 2.9 \% \\ \text { 11. R. muscosa-4 } & 299 & 314 & 313 & 186 & 217 & 160 & 147 & 42 & 43 & 9 & - & 2.8 \% & 3.0 \% & 3.3 \% & 3.1 \% \\ \text { 12. R.muscosa-5 } & 301 & 314 & 314 & 188 & 221 & 159 & 143 & 53 & 54 & 52 & 57 & - & 1.8 \% & 1.8 \% & 1.8 \% \\ \text { 13. R. muscosa-6 } & 300 & 322 & 314 & 189 & 229 & 165 & 143 & 58 & 59 & 56 & 61 & 36 & - & 0.2 \% & 0.2 \% \\ \text { 14. } \text {. muscosa-7 } & 305 & 325 & 319 & 194 & 232 & 168 & 148 & 61 & 62 & 61 & 66 & 37 & 5 & - & 0.3 \% \\ \text { 15.R.muscosa-8 } & 302 & 321 & 313 & 190 & 228 & 165 & 147 & 58 & 59 & 58 & 63 & 36 & 4 & 7 & -\end{array}$

a Percentage sequence divergence is shown above the diagonal, and number of base substitutions between sequences is shown below the diagonal. Rana muscosa populations are numbered as under Materials and Methods and are abbreviated as follows: $R$. muscosa-1, north Plumas Co.; R. muscosa-2, south Plumas Co.; R. muscosa-3, Alpine Co.; R. muscosa-4, Tuolumne Co.; R. muscosa-5, Fresno Co.; R. muscosa-6, San Gabriel Mtns.; R. muscosa-7, San Jacinto Mtns.; and R. muscosa-8, San Bernardino Mtns. 


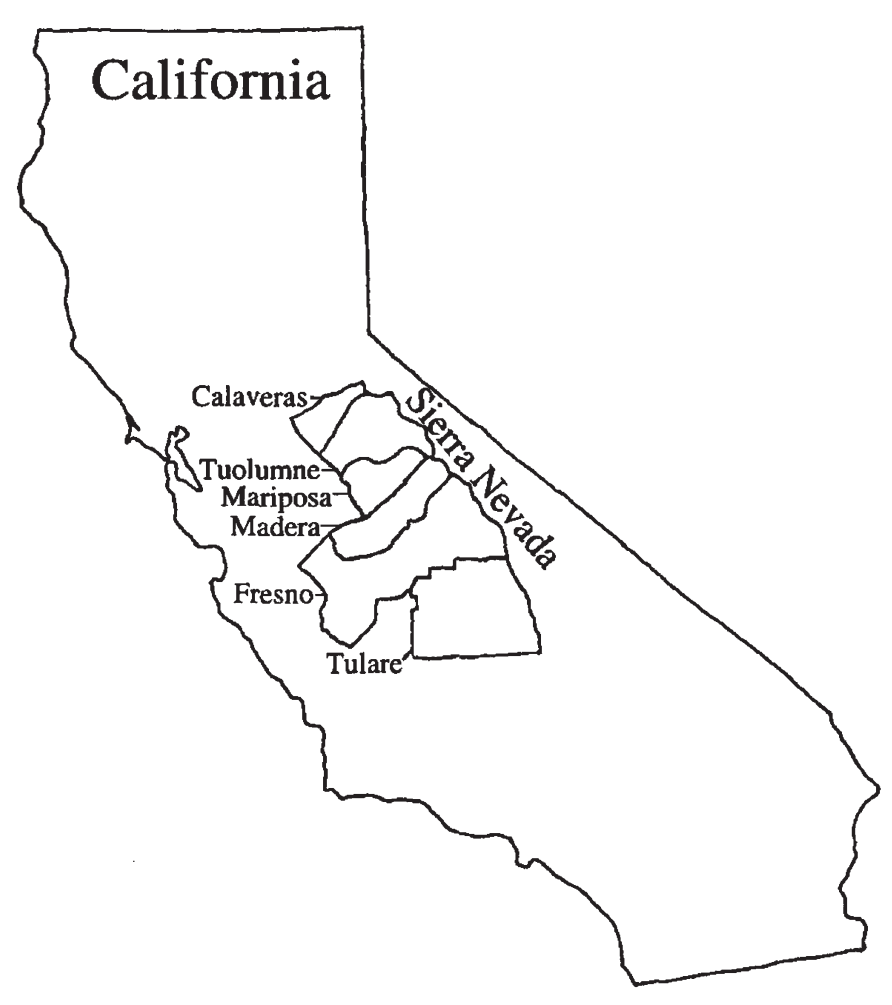

Figure 6. Map of California showing counties located in the central and southern Sierra Nevada where fragmentation of amphibian and reptilian taxa is known to occur. Patterns of fragmentation in mitochondrial DNA among amphibian and reptilian taxa from the Sierra Nevada are summarized in Table 5. The eastern boundaries of counties depict the crest of the Sierra Nevada. Mariposa County is not included in Table 5.

and mountain ranges in southern California (San Gabriel, San Jacinto, and San Bernardino). This phylogenetic hypothesis suggests that Sierra Nevada populations do not form a monophyletic group; monophyly of these populations is rejected by the Wilcoxon signedranks test (Table 3).

The biogeographic break in the Sierra Nevada discovered in $R$. muscosa is congruent with a pattern of fragmentation between northern and southern populations that is observed among codistributed amphibian and reptilian species (Table 5, Figure 6). The break observed in R. muscosa occurs between Kings Canyon National Park and a region slightly north of Yosemite National Park. This pattern is broadly congruent with genetic breaks between central and southern Sierra Nevada populations of the toad Bufo canorus (Shaffer et al., 2000), the salamander Ensatina eschscholtzii (Moritz et al., 1992), the snake Lampropeltis zonata (Rodriguez-Robles et al., 1999), and the newt Taricha torosa (Tan and Wake, 1995). Hence, there are now five species of amphibians and reptiles with a similar pattern of biogeographic fragmentation in the Sierra Nevada, suggesting that these species were influenced by a common vicariant event.

The timing of divergences within R. muscosa is useful for understanding biogeographic fragmentation in the Sierra Nevada of California. Applying the pairwise rate of change of $1.3 \%$ sequence divergence per million years to the R. muscosa populations, the initial divergence between the northern and the southern clades is dated at approximately 2.2 MYBP. Within each of these clades, temporal patterns of divergence are strikingly similar. The timing of divergence observed between populations from the northern Sierra Nevada and central Sierra Nevada (1.5 MYBP) appears to coincide in timing with the divergence observed between the southern Sierra Nevada population and the southern California populations (1.4 MYBP). This result suggests that initial divergence within $R$. muscosa occurred in the Sierra Nevada during the late Pliocene, and that further divergence within each of the northern and southern clades occurred in the Pleistocene. The fact that divergences within the northern and southern clades coincide in timing suggests a common vicariant event, such as climatic effects of Pleistocene glaciation.

The three populations in the mountains of southern California are isolated by arid valleys. However, the similarity of mitochondrial DNA sequences (Table 4) derived from these populations indicates recent contact, probably over the last few hundred thousand years.

Table 5. Patterns of Fragmentation in Mitochondria1 DNA among Amphibian and Reptilian Taxa from the Sierra Nevada ${ }^{a}$

\begin{tabular}{|c|c|c|c|c|c|}
\hline Taxon & Calaveras Co. & Tuolumne Co. & Madera Co. & Fresno Co. & Tulare Co. \\
\hline Rana muscosa & & $\mathrm{N}$ & & $S$ & \\
\hline Lampropeltis zonata & & & $\mathrm{N}$ & & $S$ \\
\hline Taricha torosa & & & & $\mathrm{N}$ & $S$ \\
\hline
\end{tabular}

${ }^{a}$ Counties in the Sierra Nevada of California are listed across the top of the table from north to south (see Figure 6). N and S refer to the southernmost extent of the northern mitochondrial haplotypes and the northernmost extent of the southern mitochondrial haplotypes, respectively. Data are from Moritz et aL (1992; E. eschscholtzii), this study (R. muscosa), Shaffer et al. (2000; B. canorus), Rodriguez-Robles et al. (1999; L. zonata), and Tan and Wake (1995; T. torosa). 
Implications for Conservation of $R$. muscosa

Biogeographic studies documenting genetic fragmentation within species ranges can be helpful in making conservation decisions. The high-elevation frog, $R$. muscosa, occurs in some of the most pristine habitats in North America, but extinction of populations is occurring rapidly (Vredenburg et al., 2001). The divergences found within R. muscosa suggest at least four evolutionarily distinct units within the species. Statistical support for evolutionarily distinct populations from the northern Sierra Nevada, central Sierra Nevada, southern Sierra Nevada, and southern California mountains is obtained (Table 3). Only a single population still exists in each of the San Gabriel, San Jacinto, and San Bernardino Mountains of southern California with less than 200 adults among the three populations, making conservation of these populations a management priority (Vredenburg et al., 2001). Populations in the central and northern Sierra Nevada are also close to extinction (Vredenburg et al., 2001). Only in the southern Sierra Nevada are there any apparently healthy populations remaining, but they are few in number (three or four populations; Vredenburg et al., 2001). More sampling is needed throughout the Sierra Nevada to delineate the boundaries of the three potential management units (Moritz, 1994; Moritz and Faith, 1998) identified here. Work in the Sierra Nevada should be conducted rapidly, as the central Sierra Nevada population sampled from Tuolumne County for this study is already extinct. The fact that $R$. muscosa, a species occurring primarily on pristine government land, is on the verge of extinction throughout its range demonstrates that land acquisition is only a first step in the preservation of species and suggests that more work must be done to understand the mechanisms behind population declines. Conservation research should apply phylogenetic analyses to delimit management units in conjunction with field studies that test mechanisms driving population declines.

\section{Acknowledgments}

We thank Carla Cicero, Jens Vindum, and David B. Wake for tissue samples, and Nikolai Orlov and Theodore J. Papenfuss for field assistance. This work was supported by grants from the National Science Foundation (DEB-9726064 to A.L., J.R.M., and Theodore J. Papenfuss), National Geographic Society (4110-89 and 487293 to Theodore J. Papenfuss and J.R.M.), the California Academy of Sciences, predoctoral fellowships from the Howard Hughes Medical Institute to J.L.S. and J.A.B., and USGS-WERC (00WRSA0023 to V.V.) .

\section{Appendix}

Alternative hypotheses used in Wilcoxon signedranks tests (Felsenstein, 1985; Templeton, 1983). Lengths of trees are given in parentheses. Taxa are labeled as in Figure 1.

The most parsimonious tree derived by constraining the $R$. boylii group not to form a monophyletic group (length of 1253 steps): A1. (R. catesbeiana, (R. sylvatica, ((R. temporaria, (R. pretiosa, (R. aurora, (R. cascadae, (() $\mathrm{N}$. Plumas Co.-1, S. Plumas Co.-2), (Alpine Co.-3, Tuolumne Co.-4)), (Fresno Co.-5, ((San Gabriel Mtns.-6, San Jacinto Mtns.-7), San Bernardino Mtns.- 8))))))), R. boy(ii))).

The most parsimonious tree derived by constraining $R$. boylii and $R$. muscosa to form a monophyletic group (length of 1264 steps): B1. (R. catesbeiana, (R. sylvatica, $(R$. temporaria, $(((R$. boylii, (((N. Plumas Co.-1, S. Plumas Co.2). (Alpine Co.-3, Tuolumne Co.-4)), (Fresno Co.-3, ((San Gabriel Mtns.-6, San Jacinto Mtns.-7), San Bernardino Mtns.-8)))), (R. aurora, R. cascadae)), R. pretiosa)))) .

The most parsimonious tree derived by constraining R. muscosa populations from the Sierra Nevada to form a monophyletic group (length of 1247 steps): C1. (R. catesbeiana, (R. sylvatica, (R. temporaria, ( $R$. boylii, $R$. pretiosa), (R. aurora, (R. cascadae, (((). Plumas Co.-1, S. Plumas Co.-2), (Alpine Co.-3, Tuolumne Co.- 4)), Fresno Co.-5). ((San Gabriel Mtns.-6, San Jacinto Mtns.-7), San Bernardino Mtns.-8)))) )))).

The most parsimonious tree derived by constraining R. muscosa populations from the northern Sierra Nevada not to form a monophyletic group (length of 1251 steps): D1. (R. catesbeiana, (R. sylvatica, (R. temporaria, ((R. boylii, R. pretiosa), (R. aurora, (R. cascadae, ((N. Plumas Co.-1, S. Plumas Co.-2, (Alpine Co.-3, Tuolumne Co.-4)), (Fresno Co.-5, ((San Gabriel Mtns.-6, San Jacinto Mtns.-7), San Bernardino Mtns.- 8))))))))).

The most parsimonious tree derived by constraining R. muscosa populations from the central Sierra Nevada not to form a monophyletic group (length of 1252 steps): E1. (R. catesbeiana, (R. sylvatica, ( $R$. temporaria, ( $R$. boylii, R. pretiosa), (R. aurora, (R. cascadae, (((). Plumas Co.1, S. Plumas Co.-2), Tuolumne Co.- 4), Alpine Co.-3). (Fresno, Co.-5, ((San Gabriel Mtns.-6, San Jacinto Mtns.7), San Bernardino Mtns.-8)))))) ))).

The most parsimonious tree derived by constraining R. muscosa populations from southern California not to form a monophyletic group (length of 1252 steps): F1. (R. catesbeiana, (R. sylvatica, (R. temporaria, ( $R$. boylii, R. pretiosa), (R. aurora, (R. cascadae, ((N. Plumas Co.-1, S. Plumas Co.-2), (Alpine Co.-3, Tuolumne Co.-4)), (((Fresno Co.-5, San Jacinto Mtns.-7), San Bernardino Mtns.-8), San Gabriel Mtns.-6)))))))). 


\section{References}

Anderson, S., Bankier, A. T., Barrell, B. G., de Bruijn, M. H. L., Coulson, A. R., Drouin, J., Eperon, I. C., Nierlich, D. P., Roe, B. A., Sanger, F., Schreier, P. H., Smith, A. J. H., Staden, R., and Young, I. G. (1981). Sequence and organization of the human mitochondrial genome. Nature 290: 457-465.

Bermingham, E., McCafferty, S. S., and Martin, A. P. (1997). Fish biogeography and molecular clocks: Perspectives from the Panamanian Isthmus. In Molecular Systematics of Fishes (T. D. Kocher and C. A. Stepien, eds.), pp. 113128. Academic Press, San Diego.

Bremer, K. (1994). Branch support and tree stability. Cladistics 10: 295-304.

Buth, D. G. (1984). The application of electrophoretic data in systematic studies. Annu. Rev. Ecol. Syst. 15: 501-522.

Camp, C. L. (1917). Notes on the systematic status of the toads and frogs of California. Univ. Calif. Publ. Zool. 17: 115-125.

Case, S. M. (1978). Biochemical systematics of members of the genus Rana native to western North America. Syst. Zool. 27: 299-31 1.

Dumas, P. C. (1966). Studies of the Rana species complex in the Pacific Northwest. Copeia 1966: 60-74.

Farris, J. S., Kluge, A., and Mickevich, M. F. (1979). Paraphyly of the Rana boylii species group. Syst. Zool. 28: 627-634.

Farris, J. S., Kluge, A., and Mickevich, M. F. (1982). Immunological distance and the phylogenetic relationships of the Rana boylii species group. Syst. Zool. 31: 479-491.

Felsenstein, J. (1985). Confidence limits on phylogenies with a molecular clock. Syst. Zool. 34: 152-161.

Green, D. M. (1985). Biochemical identification of redlegged frogs, Rana aurora draytoni (Ranidae) at Duckwater, Nevada. Southwest. Nat. 30: 614-616.

Green, D. M. (1986a). Systematics and evolution of western North American frogs allied to Rana aurora and Rana boylii: Karyological evidence. Syst Zool. 35: 273-282.

Green, D. M. (1986b). Systematics and evolution of western North American frogs allied to Rana aurora and Rana boylii: Electrophoretic evidence. Syst. Zool. 35: 283-296.

Green, D. M., Kaiser, H., Sharbel, T. F., Kearsley, J., and McAllister, K. R. (1997). Cryptic species of spotted frogs, Rana pretiosa complex, in western North America. Copeia 1997: 1-8.

Hillis, D. M., and Davis, S. K. (1986). Evolution of ribosomal DNA: Fifty million years of recorded history in the frog genus Rana. Evolution 40: 1275-1288.

Hollander, M., and Wolfe, D. A. (1973). Nonparametric Statistical Methods, Wiley, New York.
Kumazawa, Y., and Nishida, M. (1993). Sequence evolution of mitochondria] tRNA genes and deep-branch animal phylogenetics. J. Mol. Evol. 37: 380-398.

Larson, A. (1998). The comparison of morphological and molecular data in phylogenetic systematics. In Molecular Approaches to Ecology and Evolution (R. DeSalle and B. Schierwater, eds.), pp. 275-296. Birkhauser, Basel.

Mabee, P. M., and Humphries, J. (1993). Coding polymorphic data: Examples from allozymes and ontogeny. Syst. Biol. 42: 166-181.

Macey, J. R., and Verma, A. (1997). Homology in phylogenetic analysis: Alignment of transfer RNA genes and the phylogenetic position of snakes. Mol. Phylogenet. Evol. 7: 272-279.

Macey, J. R., Larson, A., Ananjeva, N. B., Fang, Z., and Papenfuss, T. J. (1997a). Two novel gene orders and the role of light-strand replication in rearrangement of the vertebrate mitochondrial genome. Mol. Biol. Evol. 14: 91-104.

Macey, J. R., Larson, A., Ananjeva, N. B., and Papenfuss, T. J. (1997b). Replication slippage may cause parallel evolution in the secondary structures of mitochondrial transfer RNAs. Mol. Biol. Evol. 14: 30-39.

Macey, J. R., Schulte, J. A., II, Ananjeva, N. B., Larson, A., Rastegar-Pouyani, N., Shammakov, S. M., and Papenfuss, T. J. (1998a). Phylogenetic relationships among agamid lizards of the Laudakia caucasia species group: Testing hypotheses of biogeographic fragmentation and an area cladogram for the Iranian Plateau. Mol. Phylogenet. Evol. 10: 118-131.

Macey, J. R., Schulte, J. A., II, Larson, A., Fang, Z., Wang, Y., Tuniyev, B. S., and Papenfuss, T. J. (1998b). Phylogenetic relationships of toads in the Bufo bufo species group from the eastern escarpment of the Tibetan Plateau: A case of vicariance and dispersal. Mol. Phylogenet Evol. 9: 80-87.

Macey, J. R., Schulte, J. A., II, Larson, A., Tuniyev, B. S., Orlov, N., and Papenfuss, T. J. (1999a). Molecular phylogenetics, tRNA evolution, and historical biogeography in anguid lizards and related taxonomic families. Mol. Phylogenet. Evol. 12: 250-272.

Macey, J. R., Wang, Y., Ananjeva, N. B., Larson, A., and Papenfuss, T. J. (1999b). Vicariant patterns of fragmentation among gekkonid lizards of the genus Teratoscincus produced by the Indian collision: A molecular phylogenetic perspective and an area cladogram for Central Asia. Mol. Phylogenet Evol. 12: 320-332.

Macey, J. R., Schulte, J. A., II, Larson, A., Ananjeva, N. B., Wang, Y., Pethiyagoda, R., Rastegar-Pouyani, N., and Papenfuss, T. J. 2000. Evaluating trans-Tethys migration: An example using acrodont lizard phylogenetics. Syst. Biol. 49: 233-256. 
Maddison, W. P., and Maddison, D. R. (1992). MacClade, analysis of phylogeny and character evolution, version 3.0, Sinauer, Sunderland, MA.

Maniatis, T., Fritsch, E. F., and Sambrook, J. (1982). Molecular Cloning: A Laboratory Manual. Cold Spring Harbor Laboratory Press, Cold Spring Harbor, NY.

Moritz, C. (1994). Applications of mitochondrial DNA analysis in conservation: A critical review. Mol. Ecol. 3: 401-411.

Moritz, C., Dowling, T. E., and Brown, W. M. (1987). Evolution of animal mitochondrial DNA: Relevance for population biology and systematics. Annu. Rev. Ecol. Syst. 18: 269-292.

Moritz, C., and Faith, D. P. (1998). Comparative phylogeography and the identification of genetically divergent areas for conservation. Mol. Ecol. 7: 419-429.

Moritz, C., Schneider, C. J., and Wake, D. B. (1992). Evolutionary relationships within the Ensatina eschscholtzii complex confirm the ring species interpretation. Syst. Biol. 41: 273-291.

Post, T. J., and Uzzell, T. (1981). The relationships of Rana sylvatica and the monophyly of the Rana boylii group. Syst. Zool. 30: 170-180.

Rodriguez-Robles, J. A., Denardo, D. E., and Staubs, R. E. (1999). Phylogeography of the California Mountain Kingsnake, Lampropeltis zonata (Colubridae). Mol. Ecol. 8: 1923-1934.

Shaffer, H. B., Fellers, G. M., Magee, A., and Voss, S. R. (2000). The genetics of amphibian declines: Population substructure and molecular differentiation in the Yosemite Toad, Bufo canorus (Anura, Bufonidae) based on single-strand conformation polymorphism analysis (SSCP) and mitochondrial DNA sequence data. Mol. Ecol. 9: 245-257.
Swofford, D. L. (1999). PAUP*. Phylogenetic Analysis Using Parsimony ("and Other Methods), Beta Version 4.0b2, Sinauer, Sunderland, MA.

Tan, A,-M., and Wake, D. B. (1995). MtDNA phylogeography of the California Newt, Taricha torosa (Caudata, Salamandridae). Mol. Phylogenet. Evol. 4: 383-394.

Templeton, A. R. (1983). Phylogenetic inference from restriction endonuclease cleavage site maps with particular reference to the evolution of humans and the apes. Evolution 37: 221-244.

Uzzell, T., and Post, T. J. (1986). Rana temporaria is not a member of the Rana boylii group. Syst. Zool. 35: 414-421.

Vredenburg, V. T., Fellers, G., and Davidson, C. (2001). Rana muscosa. In North American Amphibians: Status and Conservation (M. J. Lanoo, ed.), Smithsonian Institution Press, Washington, DC, in press.

Wallace, D. G., King, M.-C., and Wilson, A. C. (1973). Albumin differences among ranid frogs: Taxonomic and phylogenetic implications. Syst. Zool. 22: 1-13.

Weisrock, D. W., Macey, J. R., Ugurtas, I. H., Larson, and Papenfuss, T. J. (2001). Molecular phylogenetics and historical biogeography among salamandrids of the "true" salamander clade: Rapid branching of numerous highly divergent lineages with the rise of Anatolia in Mertensiella luschani. Mol. Phylogenet. Evol. 18: 450-464.

Wilson, A. C., Carlson, S. S., and White, T. J. (1977). Biochemical evolution. Annu. Rev. Biochem. 46: 573-639.

Zhang, D.-X., and Hewitt, G. M. (1996). Nuclear integrations: Challenges for mitochondrial DNA markers. Trends Ecol. Evol. 11: 247-25

Zweifel, R. G. (1955). Ecology, distribution, and systematics of frogs of the Rana boylei group. Univ. Calif. Publ. Zool. 54: 207-292. 